\title{
Sugar beets grown in the strip-tillage system at different soil cultivation depths
}

\author{
Natalia Mioduszewska ${ }^{1, *}$, Mariusz Adamski ${ }^{1}$, Ewa Osuch $^{1}$ and Andrzej Osuch $^{1}$ \\ ${ }^{1}$ Poznań University of Life Sciences, Instytute of Biosystems Engineering, Wojska Polskiego 28, 60-637 Poznań, Poland
}

\begin{abstract}
Modifications in soil cultivation affect the quality and quantity of the yield of sugar beets. The crop density, yield and the external quality of sugar beet roots are highly dependent on the preparation of soil. The intensity and precision of fragmentation of the superficial soil layer and the adequate depth of plantation must enable normal development of sugar beets. The aim of the study was to determine the dependence between the depth of soil cultivation in the strip-tillage system used for sugar beet production and the state of the plantation after the emergence of crops as well as the yield quality and quantity. The research encompassed investigations of different depths of strip-tillage systems used for sugar beet production. The systems were evaluated according to the dynamics of crops' emergence, density, yield and external quality of sugar beet roots.
\end{abstract}

\section{Introduction}

Apart from the climate and soil conditions, the technique of agrotechnical procedures largely influences the sugar beet yield quality and quantity. It ensures the adequate depth of cultivation, regular sowing depth as well as adequate and timely treatments [1-3]. The agricultural technique is decisive to the yield volume and quality, including the external quality of roots. The soil cultivation technology affects the productivity of crops, because it is simultaneously decisive to the dynamics of plants' growth at an early phase of their development and it provides plants with favourable conditions for growth and development until they are harvested [4$6]$. Well-balanced emergence affects crop density and it is decisive to the plantation density and regularity. These factors are essential for the high technological quality of yield and minimal loss during the harvesting of roots [7-8]. Individual agrotechnical procedures are supposed to guarantee yield stability and adequate technological properties of roots for sugar extraction [9].

The traditional cultivation system with soil reversion is the most common. However, in recent years, for economic and environmental reasons, the classic tillage system has been replaced by simplified systems, including the strip-tillage system [10]. Apart from the reduced energy outlay resulting in lower costs of production, simplified technologies (without ploughing) have significant influence on protection of the environment [11]. Lower intensity and frequency of treatments applied to soil protect it from degradation, aid natural biological processes and maintain its productivity [12-14].

The sugar beet production technology with the soil cultivation system, which includes selection of the cultivation depth, affects a wide range of yield characteristics, such as the root processing quality, the size and shape of the root system [7]. Therefore, the aim of this study was to determine the dependence between the depth of soil cultivation in the striptillage system used for sugar beet production and the state of the plantation after the emergence of crops as well as the yield quality and quantity.

\section{Material and methods}

A field experiment was conducted on the farm in Bełcz Mały, Commune of Wąsosz, Lower Silesian Voivodeship, Poland. Experimental plots were located on loamy sand soil, classified as IVa in the soil valuation system.

The experiment included five sugar beet growing technologies which differed in the soil cultivation depth:

1. strip tillage at a depth of $15 \mathrm{~cm}$,

2. strip tillage at a depth of $20 \mathrm{~cm}$,

3. strip tillage at a depth of $25 \mathrm{~cm}$

4. strip tillage at a depth of $30 \mathrm{~cm}$,

5. strip tillage at a depth of $35 \mathrm{~cm}$

The soil was tilled and sugar beets were sown on 4 April. Other agrotechnical procedures, such as fertilisation and treatments, were identical in all the systems and they were conducted according to the sugar beet growing guidelines. The plot area was 600

Corresponding author: natalia.mioduszewska@up.poznan.pl 
x $21.6 \mathrm{~m}$. Seeds of the Agronom sugar beet cultivar (Sesvanderhave) were sown in the plots. In theory, the sugar beet seeds were spaced at $18 \mathrm{~cm}$ from each other. A Köckerling Master combined cultivator (working width $5.4 \mathrm{~m}$ ) connected to a 12-row Kverneland Monopill SE seed drill was used in the plots.

The state of the plantation after the emergence of crops was evaluated on the basis of the emergence dynamics, the distribution of plants in rows and the crop density. The emergence was recorded every second day after the appearance of the first sugar beet seedlings at the phase of cotyledons. In each plot all emergences of sugar beets in an area of $10 \mathrm{~m}^{2}$ were counted in five replicates.

The distribution of plants in rows was evaluated as follows. In each plot 100 consecutive distances between plants in randomly selected rows were measured at an accuracy of $5 \mathrm{~mm}$ in five replicates. According to the methodology of the International Sugar Beet Institute in Brussels (IIRB - Institut International de Recherches Betteravières) the measurement results were classified into one of the three categories: double sowing, normal spacing and overspaced sowing [15]. The classification criteria were as follows:

- double sowing - plants spaced up to 0.5 XIST,

- normal spacing - plants spaced from $\leq 0.5$ XIST to

$>1.5$ XIST,

- overspaced sowing - plants spaced more than 1.5 XIST,

where:

XIST - the actual spacing between plants as calculated in measurements of normally spaced plants.

The final density of plants was calculated by counting plants in randomly selected sites of an area of $10 \mathrm{~m}^{2}$ in five replicates in each plot.

The state of the plantation before harvest was evaluated according to the yield of roots, the height of the aerial part of the roots and the morphological traits of the roots, i.e. their length, maximum diameter and weight. The height of the aerial part of the roots was measured from the leaf base to the surface of the soil. In order to measure the morphological traits the root tops were cut off manually at the upper line of the living shoot buds. The root length was measured from the site where its top was cut off to the end of the tail with a diameter of $10 \mathrm{~mm}$. The diameter was measured at the widest part of the proper root. Before the roots were weighed, their tops had been cut off and cleaned. 100 roots were collected from five randomly selected rows in each plot and the height of their aerial part, their length, maximum diameter and weight were measured.

The yield of the roots from each plot was measured according to the weight of 500 roots and the final density of sugar beets.

The space between plants in a row, the root length and weight were analysed with the Plantator ver. 2 computer program, which calculated the percentage share of the roots in the following groups and intervals [16]:

- root length:

$0-10 \mathrm{~cm} ;>10-15 \mathrm{~cm} ;>15-20 \mathrm{~cm} ;>20 \mathrm{~cm}$

- root diameter:

0-4,5 cm; >4,5-7 cm; >7-9 cm; >9-11 cm; >11-13 cm;

$>13-15 \mathrm{~cm} ;>15 \mathrm{~cm}$

- root weight:

0-300 g; >300-600 g; >600-900 g; >900-1,200 g; $>1,200-1,800 \mathrm{~g} ;>1,800 \mathrm{~g}$.

\section{Results}

Dynamics of emergence. The first emergences of sugar beets in the experimental plots began 18 days after the seeds had been sown. This means that there were average conditions in the plantation. It is assumed that under favourable conditions sugar beets start emerging 7-12 days after sowing the seeds, under average conditions - 14-18 days after sowing, whereas under unfavourable conditions - even as late as 30 days after sowing [2]. During the first measurement the smallest number of seedlings was noted in the system where the soil was cultivated at a depth of $25 \mathrm{~cm}$. This technology was characterised by the most dynamic and unequal emergence of the plants. The emergence was the most balanced in the strip-till technology where the soil was cultivated at a depth of $15 \mathrm{~cm}$. This system was characterised by the largest number of emerged plants at all the three terms of measurements. All the five cultivation systems were characterised by similar dynamics of emergence. The number of consecutive emerging plants varied comparably, without considerable deviations, except the strip-till technology at a depth of $25 \mathrm{~cm}$, where the number of plants decreased at the fourth term. The dynamics of emergence is illustrated in Figure 1.

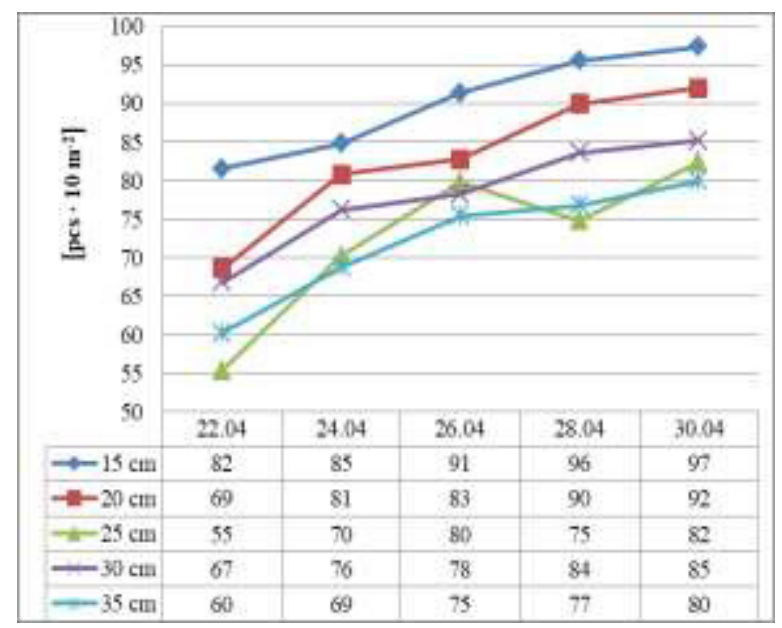

Fig. 1. The dynamics of emergence in the strip-till technology systems.

The field emergence capacity in the strip-till technology systems ranged from $69.4 \%$ to $80.2 \%$ (Table 1). The technology where the soil was cultivated at a depth of $30 \mathrm{~cm}$ was characterised by the lowest emergence capacity. The highest capacity 
was noted in the technology where the soil was cultivated at a depth of $15 \mathrm{~cm}$.

Table 1. The average field emergence capacity in the striptill technology systems [\%].

\begin{tabular}{|c|c|c|c|c|c|}
\hline Strip-tillage depth & $\begin{array}{c}15 \\
\mathrm{~cm}\end{array}$ & $\begin{array}{c}20 \\
\mathrm{~cm}\end{array}$ & $\begin{array}{c}25 \\
\mathrm{~cm}\end{array}$ & $\begin{array}{c}30 \\
\mathrm{~cm}\end{array}$ & $\begin{array}{c}35 \\
\mathrm{~cm}\end{array}$ \\
\hline $\begin{array}{c}\text { Field emergence } \\
\text { capacity }\end{array}$ & 80.2 & 72.6 & 70.3 & 69.4 & 70.2 \\
\hline
\end{tabular}

The best field emergence capacity was observed in the technologies where the soil was cultivated at depths of 15 and $20 \mathrm{~cm}$. The field emergence capacity was only satisfactory in the systems where the soil was cultivated at depths of 25,30 and $35 \mathrm{~cm}$.

Density of plants. The density of plants was diversified in all the strip-till technology systems (Fig. 2). The highest final density of plants, i.e. 99,400 plants per hectare, was noted in the system where the soil was cultivated at a depth of $15 \mathrm{~cm}$. The lowest density, i.e. 86,000 plants per ha, was observed in the strip-till system where the soil was cultivated at a depth of $30 \mathrm{~cm}$. The measurements also showed that in comparison with the standard cultivation depth of $25 \mathrm{~cm}$, when the soil cultivation was $5 \mathrm{~cm}$ shallower, the density of plants increased by 2,800 pieces per ha. When the soil cultivation depth was reduced by 10 $\mathrm{cm}$, the density of plants increased by as much as 12,200 pieces per ha. According to Gutmański [17], the optimal density of sugar beets on average soils ranges from 81,000 to $95,000 \mathrm{pcs} \cdot \mathrm{ha}^{-1}$. When the density increases, so does the yield of leaves and sugar, but the yield of roots is usually lower. At higher densities the roots are smaller, their size is more equal and they have better processing value. Therefore, the optimal density of plants was noted in the systems where the soil was cultivated at depths of $20,25,30$ and $35 \mathrm{~cm}$.

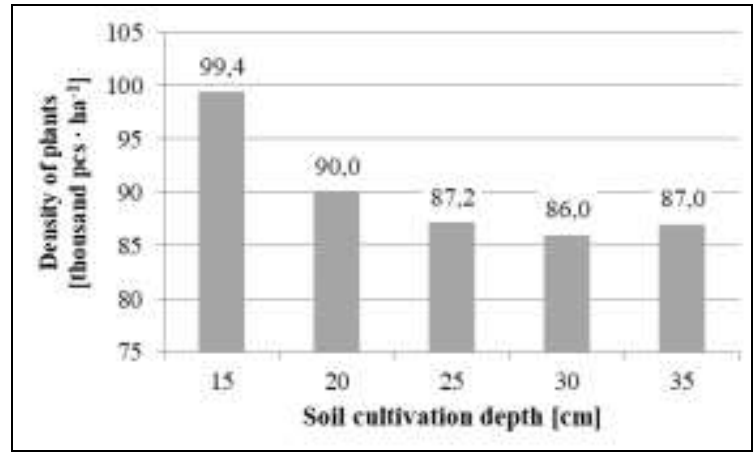

Fig. 2. The final density of sugar beets according to the strip-tillage system

Distribution of plants. Adequate distribution of plants in a row is very important not only for good density of the plantation but also for minimal loss of roots during harvest. From the point of view of the harvesting technique, irregular distribution of plants in a row, irregular heights of aerial parts of roots and considerably diversified heights of individual sugar beets in the field are unfavourable. The analysis of the results showed that the highest percentage of adequately distributed plants in a row resulted from the strip-till technology where the soil was cultivated at a standard depth of $25 \mathrm{~cm}(83.4 \%)$. A lower soil cultivation depth decreased the adequate distribution of seeds by about $2 \%$, whereas a higher depth decreased the adequate distribution of plants by as much as $8.4 \%$ (Table 2).

Table 2. The percentage of adequately distributed plants in a row according to the strip-tillage system [\%]

\begin{tabular}{|c|c|c|c|c|c|}
\hline Strip-tillage depth & $\begin{array}{c}15 \\
\mathrm{~cm}\end{array}$ & $\begin{array}{c}20 \\
\mathrm{~cm}\end{array}$ & $\begin{array}{c}25 \\
\mathrm{~cm}\end{array}$ & $\begin{array}{c}30 \\
\mathrm{~cm}\end{array}$ & $\begin{array}{c}35 \\
\mathrm{~cm}\end{array}$ \\
\hline $\begin{array}{c}\text { Percentage of } \\
\text { adequately } \\
\text { distributed plants }\end{array}$ & 81.4 & 81.6 & 83.4 & 75.2 & 75.0 \\
\hline
\end{tabular}

The remaining percentage included chiefly single gaps and less frequently - double and triple gaps (Fig. 3 ). The most gaps were noted in the systems where the soil was cultivated at depths of 30 and $35 \mathrm{~cm}$ $(17.4 \%)$. When the soil cultivation depth increased, so did the number of double and triple gaps. Their share amounted to $6 \%$ and $6.8 \%$ in the soil cultivated at depths of 30 and $35 \mathrm{~cm}$, respectively. The share of single gaps in the systems where the soil was cultivated at depths of 15, 20 and $25 \mathrm{~cm}$ amounted to $14.8 \%, 15 \%$ and $14.6 \%$, respectively. The share of double and triple gaps in these three technologies did not exceed $3.4 \%$. The share of double sown seeds in all the systems was not greater than $0.8 \%$.

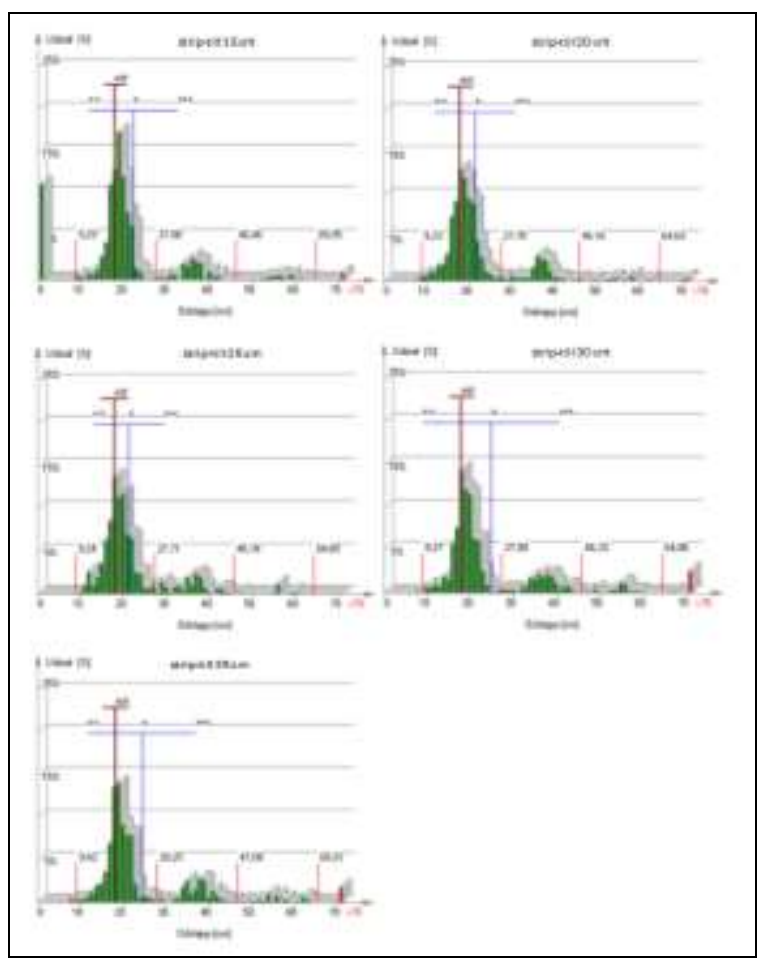

Fig. 3. The share of adequately sown plants, double sown plants and gaps according to the strip-tillage system (Share $\%$, Spacing - cm)

The strip-tillage systems did not differ significantly in the height of the aerial parts of the 
roots (Fig. 4). The average heights ranged from 4.81 $\mathrm{cm}$ to $5.98 \mathrm{~cm}$.

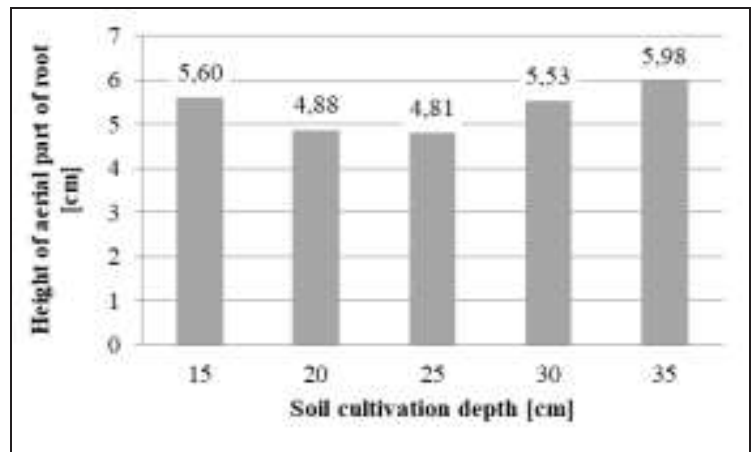

Fig. 4. The average height of the aerial part of the sugar beet roots according to the strip-tillage system

External quality of roots. The biometric traits of sugar beet roots are very important at harvest and they may affect the technological value of raw material and its suitability for processing into sugar. It is difficult to pull out heavy roots from soil. Too long roots may increase the loss during harvesting because their ends may be broken. The size of roots is also decisive to their external quality, because medium roots (500-700 g) are more suitable for processing into sugar [17]. It is noteworthy that roots with a diameter of $12-15 \mathrm{~cm}$ are the least resistant to damage, whereas those with a diameter of 7-9 $\mathrm{cm}$ are the most resistant [18-19].

The analysis of the results showed that when the soil cultivation depth was 5 and $10 \mathrm{~cm}$ greater than the standard depth $(25 \mathrm{~cm})$, the root length increased by $2.1 \mathrm{~cm}$ and $2.9 \mathrm{~cm}$, respectively (Fig. 5).

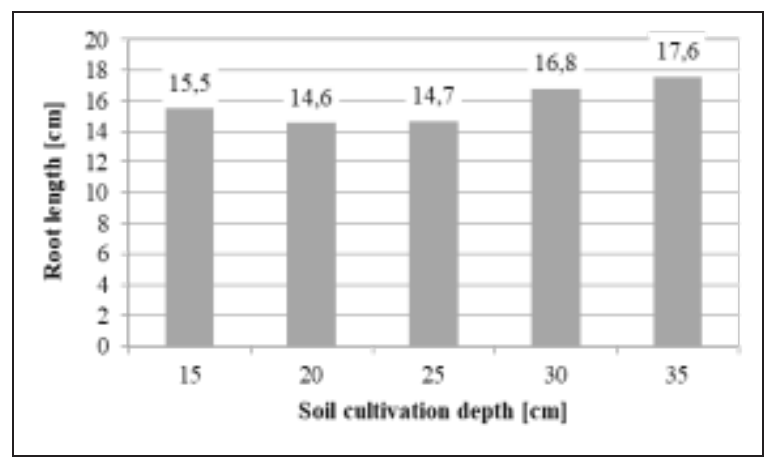

Fig. 5. The average sugar beet root length according to the strip-tillage system

The highest percentage of roots longer than $20 \mathrm{~cm}$ was noted in the systems where the soil was cultivated at depths of 30 and $35 \mathrm{~cm}$ (Fig. 6). These technologies were also characterised by the lowest percentage of the roots which were shorter than $10 \mathrm{~cm}$. The highest percentage of medium-length roots, i.e. $>10-15 \mathrm{~cm}$, was noted in the systems where the soil was cultivated at depths of 20 and $25 \mathrm{~cm}(51.8 \%$ and $47.6 \%$, respectively).

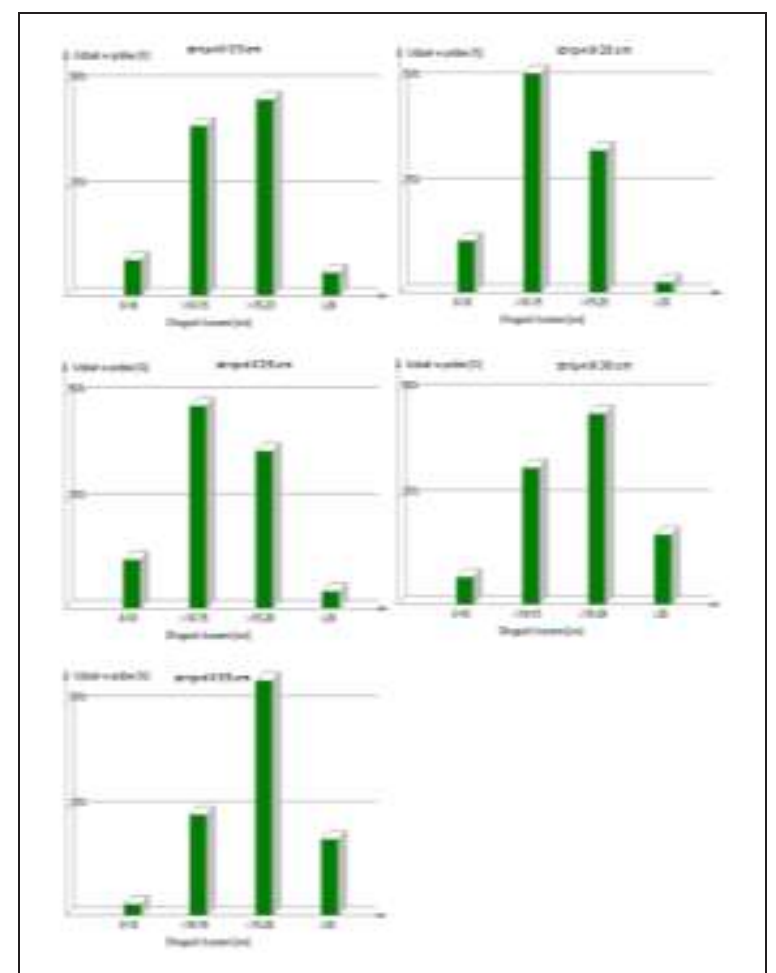

Fig. 6. The share of root lengths of $0-10 \mathrm{~cm},>10-15 \mathrm{~cm}$, $>15-20 \mathrm{~cm}$ and $>20 \mathrm{~cm}$ according to the strip-tillage system (Share in variant $-\%$, Root length $-\mathrm{cm}$ )

The soil cultivation systems did not differ significantly in the diameter of sugar beet roots (Fig. 7). The smallest average maximum diameters of 11.3 $\mathrm{cm}$ and $11.5 \mathrm{~cm}$ were noted in the systems where the soil was cultivated at depths of 20 and $25 \mathrm{~cm}$. The average maximum root diameter in the other strip-till systems ranged from 12.0 to $12.3 \mathrm{~cm}$.

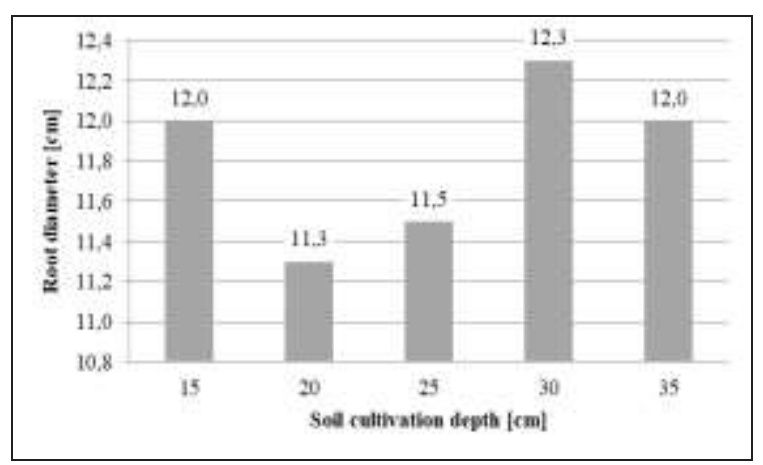

Fig. 7. The average maximum sugar beet root diameter according to the strip-tillage system

The most roots with the maximum diameters larger than $13 \mathrm{~cm}$, which were the most vulnerable to damage [17], were noted in the strip-tillage technology where the soil was cultivated at a depth of $15 \mathrm{~cm}$ (Fig. 8). 


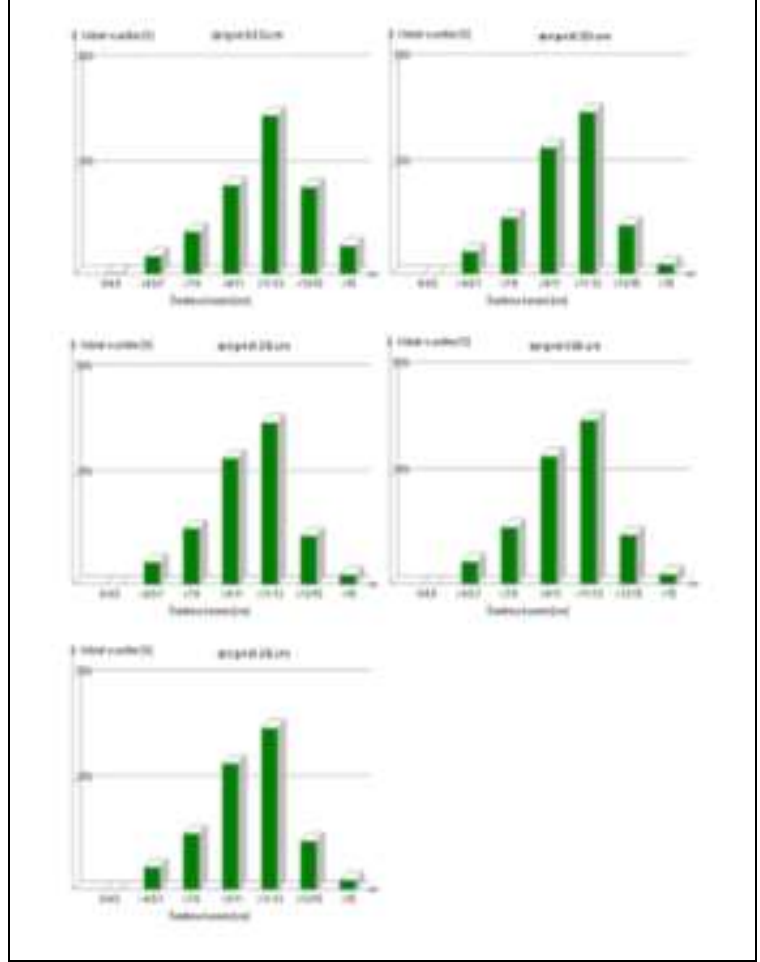

Fig. 8. The share of root diameters of $0-4.5 \mathrm{~cm} ;>4.5-7 \mathrm{~cm}$; $>7-9 \mathrm{~cm} ;>9-11 \mathrm{~cm} ;>11-13 \mathrm{~cm} ;>13-15 \mathrm{~cm}$ and $>15 \mathrm{~cm}$ diameter according to the strip-tillage system (Share in sample - \%, Root diameter - cm)

The smallest average root weights of 873.0 and $904.8 \mathrm{~g}$ were noted in the systems where the soil was cultivated at depths of 20 and $25 \mathrm{~cm}$, respectively. The average root weight in the other variants was larger than $1,000 \mathrm{~g}$.

The analysis of the percentage share of roots in individual weight intervals showed that the striptillage systems where the soil was cultivated at depths of 20 and $25 \mathrm{~cm}$ resulted in the best conditions for the development of medium roots, weighing 600-900 g. The highest percentage of the heaviest roots was noted in the strip-tillage systems where the soil was cultivated at depths of 15, 30 and $35 \mathrm{~cm}$ (Fig. 10).

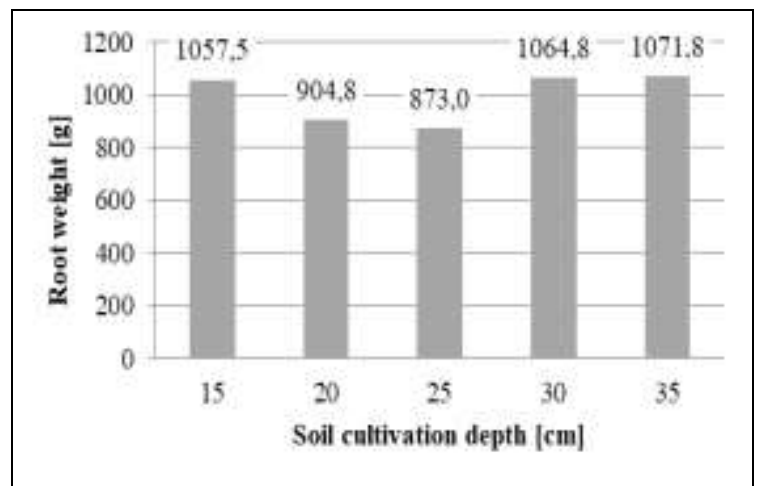

Fig. 9. The average sugar beet root weight according to the strip-tillage system

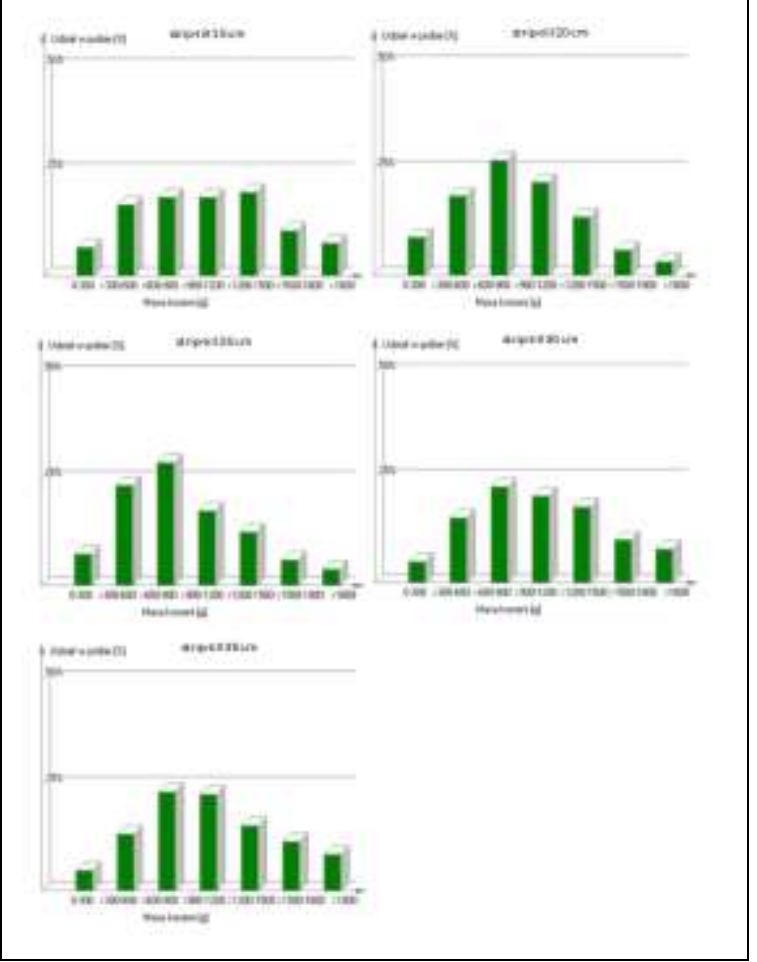

Fig. 10. The percentage of roots in weight intervals of 0$300 \mathrm{~g}>300-600 \mathrm{~g}>600-900 \mathrm{~g}>900-1,200 \mathrm{~g}>1,200-1,800 \mathrm{~g}$ $>1,800 \mathrm{~g}$ according to the strip-tillage system (Share in sample - \%, Root weight - cm)

The analysis of the results showed that the yield of roots was the lowest in the system where the soil was cultivated at a standard depth of $25 \mathrm{~cm}$. Both smaller and greater soil cultivation depths resulted in higher yields (Fig. 11).

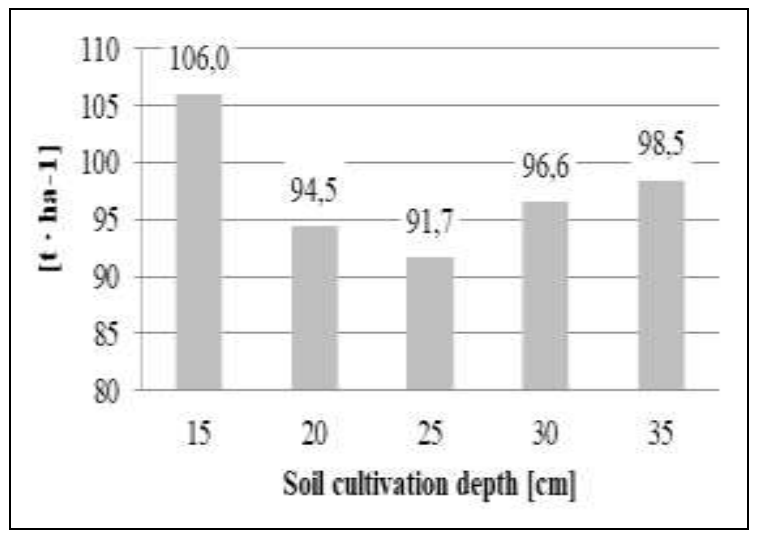

Fig. 11. The yield of roots according to the strip-tillage system

The analysis of the yield of roots showed that when the soil cultivation depth was $10 \mathrm{~cm}$ smaller than the standard depth $(25 \mathrm{~cm})$, the yield increased by as much as $14.3 \mathrm{t} \cdot \mathrm{ha}^{-1}$.

The analysis of the results showed that when the soil cultivation depth was reduced from the standard $25 \mathrm{~cm}$ to 15 or $20 \mathrm{~cm}$, neither the state of the plantation after the emergence of plants nor the external quality of the yield became worse. The results also showed that the yield of sugar beets did 
not decrease whereas the energy outlay could be limited, e.g. by reducing the consumption of fuel.

\section{Conclusions}

1. The strip-tillage system at a depth of $15 \mathrm{~cm}$ resulted in the highest density and the highest yield of sugar beets.

2. The soil cultivation depths of 30 and $35 \mathrm{~cm}$ were characterised by the heaviest weights and the greatest diameters and lengths of roots.

3. The reduction of the standard soil cultivation depth of $25 \mathrm{~cm}$ did not decrease the yield or the external quality of roots.

4. The greatest soil cultivation depths of 30 and 35 $\mathrm{cm}$ in the strip-tillage system caused a decrease in the number of adequately spaced plants and reduced their density.

5. The strip-tillage systems did not differ greatly in the parameters under analysis, but the striptillage system where the soil was cultivated at a standard depth of $25 \mathrm{~cm}$ tended to reduce the size of roots and decrease the yield.

\section{References}

1. J. Mikita, I. Gutmański, Biuletyn IHAR. 222. 171-183 (2002)

2. N. Mioduszewska, J. Przybył, D. Wojcieszak, Technologia uprawy buraków cukrowych a powschodowy stan plantacji. Aktualne problemy inżynierii biosystemów, Wyd. UP Poznań. Monografia pod red. M. Lipińskiego i J. Przybyła. ISBN 978-83-7160-731-8. 33-41. (2014)

3. P. Okoń, J. Rudowicz-Nawrocka, P. Boniecki, K. Koszela, M. Zaborowicz, P. Idziaszek, K. Górna, N. Mioduszewska, The application supports the process of identifying the diseases that occur on the leaves of sugar beet, Proc. SPIE 10420, Ninth International Conference on Digital Image Processing (ICDIP 2017), 1042007 (2017/07/21); doi: 10.1117/12.2281724

4. F. Borówczak, Przyrodnicze $i$ agrotechniczne uwarunkowania plonowania buraków cukrowych. Nowoczesna uprawa buraków cukrowych. Pr. zbior. pod red. W. Grzebisza. Wyd. AR Poznań. ISBN 83-7160-273-1, 20-28 (2002)

5. R. Gaj, A. Budka, A. Niewiadomska, J. Przybył, N. Mioduszewska, J. Elem., 20(3): 571-584. DOI: $10.5601 /$ jelem.2015.20.1.772 (2015)

6. A. Niewiadomska, R. Gaj, J. Przybył, A. Budka, N. Mioduszewska, A. Wolna-Maruwka, Pol. J. Environ. Stud. vol. 25, no. 5. ISSN 1230-1485. s. 1803-1812 (2016)

7. B. Michalska-Klimczak, Z. Wyszyński. Zeszyty Problemowe postępów nauk rolniczych. Zeszyt 556. 181-191. (2010)
8. G. Niedbała, N. Mioduszewska, W. Mueller, P. Boniecki, D. Wojcieszak, K. Koszela, S. Kujawa, R. J. Kozłowski, K. Przybył, Use of computer image analysis methods to evaluate the quality topping sugar beets with using artificial neural networks, Proc. SPIE 10033, Eighth International Conference on Digital Image Processing (ICDIP 2016), 100332M (2016/08/29); doi: 10.1117/12.2244875

9. M. Bzowska-Bakalarz, M. Banach, Inżynieria Rolnicza. Nr 3(63), 95-102 (2005)

10. L. Zimny, A. Zych, R. Wacławowicz, Zeszyty Problemowe Postępów Nauk Rolniczych. Nr 581. 135-145 (2015)

11. J. Gorzelany, G. Zaguła, M. Zardzewiały. Inżynieria Rolnicza. Nr 8(133). 143-151. (2011)

12. C. K. Cavalaris, T. A. Gemtos, CIGR Journal of Scientific Research and Development. Manuscript LW 01008 . Nr IV. (2002)

13. L. Zimny, P. Kuc, R. Wacławowicz, A. Zych Zesz. Nauk. UP Wroc., Rol. CVIII, 599. 75-84 (2014)

14. D. Tarkalson, D. L. Bjorneberg, A. Moore, Journal of Sugar Beet Research. 49(3-4). 79-102 (2012)

15. J. P. Vandergeten, J. P. Van der Linden, P. Jarvis, E. Leveque, D. Guiraud de Willot, K. H. Kromer, Test Procedures for Measuring the Quality in Sugar Beet Production - Seed Drillability, Precision Seeders, Harvesters, Cleaner Loaders. IIRB. Bruksela (2004)

16. J. Przybył, P. Błażczak, A. Urban, Inżynieria Rolnicza. 2(35), 249-258 (2002)

17. I. Gutmański, Produkcja buraka cukrowego. Pr. zbior. Państwowe Wyd. Rolnicze i Leśne. Poznań (1991)

18. M. Bzowska-Bakalarz, Wtaściwości mechaniczne korzeni buraków cukrowych Rozprawa habilitacyjna. 166. AR Lublin (1994)

19. M. Rudy, R. Stanisławczyk, E. Głodek. Zeszyty problemowe postępów nauk rolniczych. Z. 558. 231-238 (2011) 